\title{
Gastrointestinal Stromal Tumor of the Rectovaginal Septum, a Diagnosis Challenge
}

\author{
Josefa Marcos Sanmartín, María José Román Sánchez, \\ José Antonio López Fernández, Óscar Piñero Sánchez, \\ Amparo Candela Hidalgo, Hortensia Ballester Galiana, \\ Natalia Esteve Fuster, Aránzazu Saco López and \\ Juan Carlos Martínez Escoriza \\ Department of Gynaecology, Hospital General Universitario, \\ Alicante \\ Spain
}

\section{Introduction}

Gastrointestinal stromal tumors (GISTs) are the most common mesenchymal tumors of the gastrointestinal tract. These are rare tumors representing approximately $0.1-3.0 \%$ of all gastrointestinal cancers and approximately $5 \%$ of all soft tissue sarcomas (Reid et al., 2005; Fletcher et al., 2002). Due to their similar appearance by light microscopy, GISTs were previously thought to be smooth muscle neoplasms, and most were classified as leiomyosarcoma (Reid et al, 2005). (Table 1) The precise cellular origin of these tumors has been proposed to be the interstitial cell of Cajal, an interstitial pacemaker cell (Connolly et al., 2003).

It is important to differentiate between GISTs, which constitute approximately $80 \%$ of gastrointestinal mesenchymal tumors, and the less common gastrointestinal non-epithelial neoplasms, leiomyoma, leiomyosarcoma (10-15\% of mesenchymal tumors), schwannomas $(5 \%)$, and other malignant disorders.

Nearly all GISTs (90-100\%) display strong immunohistochemical staining for kit (CD 117), and this can be used in their differential diagnosis and positive identification. Smooth muscle neoplasms, and neurogenic tumours (schwannoma) typically do not show a positive expression of CD117, but can be distinguished from GISTs by histological and clinical means. It is recommended that CD117 immunostaining should be performed to facilitate the diagnosis of GISTs for spindle cell or epithelioid tumors arising the gastrointestinal tract. Diagnosis, however, should not be based purely on CD117 expression. The diagnosis of CD117 negative GISTs should only be made with extreme care. If there is evidence of desmin or S-100 expression and the tumor is not associated with the gut wall then a diagnosis of a kit negative GIST should not be made.

Mutations of kit are common in malignant GISTs and lead to constitutional activation of tyrosine kinase function, which causes cellular proliferation and resistance to apoptosis. It is also important the stain for the myeloid stem cell antigen CD 34 in 53\% to $71 \%$ of cases. (Connolly et al., 2003; De Matteo et al., 2000; Saund et al., 2004, Yamamoto et al., 2004). 


\begin{tabular}{|l|l|l|l|l|l|}
\hline & CD 117 & CD 34 & SMA & Desmin & S-100 \\
\hline GIST & + & + & + & & + \\
& $\begin{array}{l}\text { Around } \\
95 \%\end{array}$ & $60-70 \%$ & $30-40 \%$ & Very rare & $5 \%$ \\
\hline $\begin{array}{l}\text { Smooth } \\
\text { Muscle } \\
\text { Tumor }\end{array}$ & - & $\begin{array}{l}+ \\
10-15 \%\end{array}$ & + & + & Rare \\
\hline Schwannoma & - & + & - & - & + \\
\hline
\end{tabular}

Table 1. Immunohistochemical schema for the differential diagnosis of spindle cell tumors of the gastrointestinal tract. (Reid et al., 2005).

Approximately, 30\% of GISTs are malignant. The principal sites of metastasis are the liver and the peritoneal cavity. Rarely, GISTs metastasise to other sites such as the lymph nodes, lung, bone (Reid et al., 2005), and muscle (Pasku et al., 2008).

The most frequent anatomic sites of tumor origin are the stomach $(70 \%)$, the small intestine (20-30\%), esophagus, colon and rectum (10\%) (Reid et al., 2005). (Table 2).

\begin{tabular}{|l|l|}
\hline Site & Percentage \\
\hline Stomach & $60-70 \%$ \\
\hline Small intestine & $20-30 \%$ \\
\hline Oesophagus, mesentery, omentum, colon and rectum & $10 \%$ \\
\hline
\end{tabular}

Table 2. Site of GISTs. (Reid et al., 2005)

They are rare before the age of 40 years and very rare in children, with a median age of 50-60 years. Some data show a slight male predominance. (Reid et al., 2005).

The symptoms (Table 3) (Nickl et al., 2004; Reid et al., 2005, Saund et al., 2004) of GISTs are non-especific and depend on the size and location of the lesion. Small GISTs (2cm or less) are usually asymptomatic and are detected during investigations or surgical procedures of unrelated causes. The vast majority of these are low-risk for malignancy. The most common symptom is gastrointestinal bleeding which is present in approximately $50 \%$ of patients. Systemic symptoms such as fever, night sweats, and weight loss are common in GISTs and very rare in other sarcomas. Patients with larger tumors may experience abdominal discomfort or develop a palpable mass. Up to $25 \%$ of patients present with acute haemorrhage into the intestinal tract or peritoneal cavity from tumor rupture. Symptomatic oesophageal GISTs typically present with dysphagia, while gastric and small intestinal GISTs often present with vage symptoms leading to their eventual detection by gastroscopy or radiology. Most duodenal GISTs occur in the second part of the duodenum where they push or infiltrate into the pancreas. Colorectal GISTs may manifest with pain and gastrointestinal obstruction, and lower intestinal bleeding. Rectal tumors are usually deep intramural tumors.

\begin{tabular}{|l|l|}
\hline Symptoms & Incidence \\
\hline Abdominal pain & $20-50 \%$ \\
\hline Gastrointestinal bleeeding & $50 \%$ \\
\hline Gastrointestinal obstruction & $10-30 \%$ \\
\hline Asymptomatic & $20 \%$ \\
\hline
\end{tabular}

Table 3. Symptoms of GIST at diagnosis. (Reid et al., 2005) 
The pathogenesis of GISTs has been established by the observation that kit is highly expressed and mutated in almost all tumors (Taniguchi et al., 1999). The use of antibodies to kit, as part of an immunohistochemical panel and in combination with traditional histological and clinical examinations, means that it is possible to distinguish clearly GISTs from other gastrointestinal tract tumours. In addition, the tyrosine kinase inhibitor imatinib mesilate (Gleevec $\left.{ }^{\mathrm{TM}}\right)$ represents a major breakthrough in the treatment of GISTs, as it has significant antitumour activity in these neoplasms, which are generally resistant to cytotoxic chemotherapy (Zalupski et al. 1991; Ronellenfitsch et al., 2008). A second targeted tyrosine kinase inhibitor, sunitinib malate (Sutent ${ }^{\mathrm{TM}}$ ), has been approved for the treatment of imatinibresistant gastrointestinal stromal tumors. (Raut et al., 2007).

Surgical resection is the principal treatment for GISTs. Evaluation of the resecability of a GIST is determined by the surgeon and depends on the stage and the individual patient's fitness for surgery. The primary goal of surgery is complete resection of the disease with avoidance of tumor rupture. Care is necessary as GISTs are often soft and fragile, and tumor rupture may seed implants in the peritonel cavity and liver. A wide local resection with macroscopic removal of the entire tumor to achieve microscopic clearance is recommended. An adequate cancer margin is considered to be $2 \mathrm{~cm}$ (Reid et al.,2005) but this is not always possible.

It is recommended that all patients should be followed up. Observation is the current standard of care after complete resection of a primary tumor. Following initial assessment, high risk tumors should have computed tomography (CT) every 6 months for 3 years. However, in all cases, if symptoms become evident an early CT may be appropriate. Regardless of risk, clinic review should be indefinite, as these tumors may recur several years after apparently curative resection.

There was no currently accepted adjuvant therapy regimen before Gleevec ${ }^{\mathrm{TM}}$ was approved. Gleevec $^{\mathrm{TM}}$ is generally well tolerated at doses up to $800 \mathrm{mg} /$ day. Toxicities include nausea and vomiting, diarrhoea, myalgia, skin rash and occasional neutropenia (Table 4). Although frequent, these toxicities rarely require withdrawal of Gleevec ${ }^{\mathrm{TM}}$.

\begin{tabular}{|l|l|}
\hline Blood and lymphatic system disorders & Neutropenia, thrombocytopenia, anaemia \\
\hline Nervous system disorders & Headache \\
\hline Gastrointestinal disorders & $\begin{array}{l}\text { Nausea, vomiting, diarrhoea, dyspepsia, } \\
\text { abdominal pain }\end{array}$ \\
\hline Skin and subcutaneous tissue disorders & $\begin{array}{l}\text { Periorbital oedema, } \\
\text { dermatitis /eczema / rash }\end{array}$ \\
\hline $\begin{array}{l}\text { Musculoskeletal, connective tissue } \\
\text { and bone disorders }\end{array}$ & $\begin{array}{l}\text { Muscle spam and cramps, musculoskeletal } \\
\text { pain including arthralgia }\end{array}$ \\
\hline $\begin{array}{l}\text { General disorders and } \\
\text { Administration site conditions }\end{array}$ & Fluid retention and oedema, fatigue \\
\hline
\end{tabular}

Table 4 . Very common (>1/10) adverse reactions with imatinib mesylate (Reid et al., 2005)

\section{Gastrointestinal stromal tumours of the rectovaginal septum}

GISTs located out of the gastrointestinal tract (Extragastrointestinal stromal tumors, EGISTs) are very uncommon; and those that arise in the rectovaginal septum are highly infrequent entities, that pose a challenge due to the lack of diagnostic suspicious (Ceballos et al., 2004; 
Hellan et al., 2006; Lam et al., 2006; Marcos et al., 2010; Mussi et al., 2008; Nagase et al., 2007; Nasu et al., 2004; Takano et al., 2006; Tooru et al., 2001; Valera et al., 2008; Weppler et al., 2005; Zang et al., 2009).

The main differential diagnosis of EGISTs of the vagina and rectovaginal septum is leiomyoma and leiomyosarcoma. Like GISts, both leiomyoma and leiomyosarcoma are rare primary lesions of the vagina. Histologically, leiomyomas and leiomyosarcomas are usually composed of spindle cells that are arranged in fascicles. In contrast to GISTs, which have very fibrillary, pale pink cytoplasm, smooth muscle tumors have dense, brightly eosinophilic cytoplasm. In addition, leiomyosarcomas tend to exhibit pleomorphism, which is unusual in GIST; smooth muscle tumors are immunoreactive for smooth muscle actin and desmin and are negative for kit (CD117). Like GISTs, smooth muscle tumors can be positive for CD34. Epithelioid smooth muscle tumors can mimic both epithelioid GIST and carcinoma, which are the most likely soft tissue neoplasm to arise in this location. Carcinomas are usually strongly positive for cytokeratins, whereas GISTs rarely express this antigen. Nerve sheath tumors, especially schwannomas are diffusely and strongly positive for S-100 protein and negative for kit. Aggressive angiomyxoma is rare but tends to occur in the deep soft tissues of the vulva and vagina. In contrast to GIST, these lesions are always paucicellular, contain myxoid stroma and a prominent vascular pattern, are positive for actine, desmin, estrogen receptor, and progesterone receptor, and negative for kit. Angiomyofibroblastoma is another spindle cell lesion that enters into the differential diagnosis. They are typically located in the superficial soft tissues and are variably cellular with a prominent vascular pattern. They are negative for kit and positive for actin, desmin, estrogen receptor and progesterone receptor. Also, dermatofibrosarcoma protuberans can arise in the vulvovaginal region; they are uniformly positive for CD34, but can be distinguished from GIST because are negative for kit.

Because of their malignant potential and recent advances in the management of GISTs with imatinib mesylate (Gleevec ${ }^{\mathrm{TM}}$ ) (De Matteo et al., 2007; Park et al., 2008; Verma et al., 2009), it is imperative that these tumors are diagnosed correctly despite of the similarity in their structure and size. Conventional radiotherapy and chemotrapy are useless in the treatment of these tumors, thus this fact makes more important the misdiagnosis of these masses.

However, the current definitive treatment for GIST, including EGIST, is surgical.

In this chapter, we describe a recent case of EGIST located in the rectovaginal septum, and a rewiev of the recent literature in this field.

\subsection{Case report}

We report the case of a 75-year-old woman with a GIST tumor in the rectovaginal septum. She consulted because of unpleasant feelings in the vagina and constipation that had started few months ago. Colonoscopy (Fig. 1.) revealed a probably submucosal tumor of $4 \mathrm{~cm}$ in the anterior wall of the lower rectum, but it could not confirm the origin (gynecological or gastrointestinal). The patient was admitted in our Department for close examination and eventual treatment.

During the physical examination we saw a tumour of about $5 \mathrm{~cm}$ that stunned in the posterior wall of the vagina; pelvic exmination revealed (Fig. 2.) a $5 \mathrm{~cm}$ hard, wellcircumscribed heterogeneous tumor, with a clear border in the rectovaginal space. 


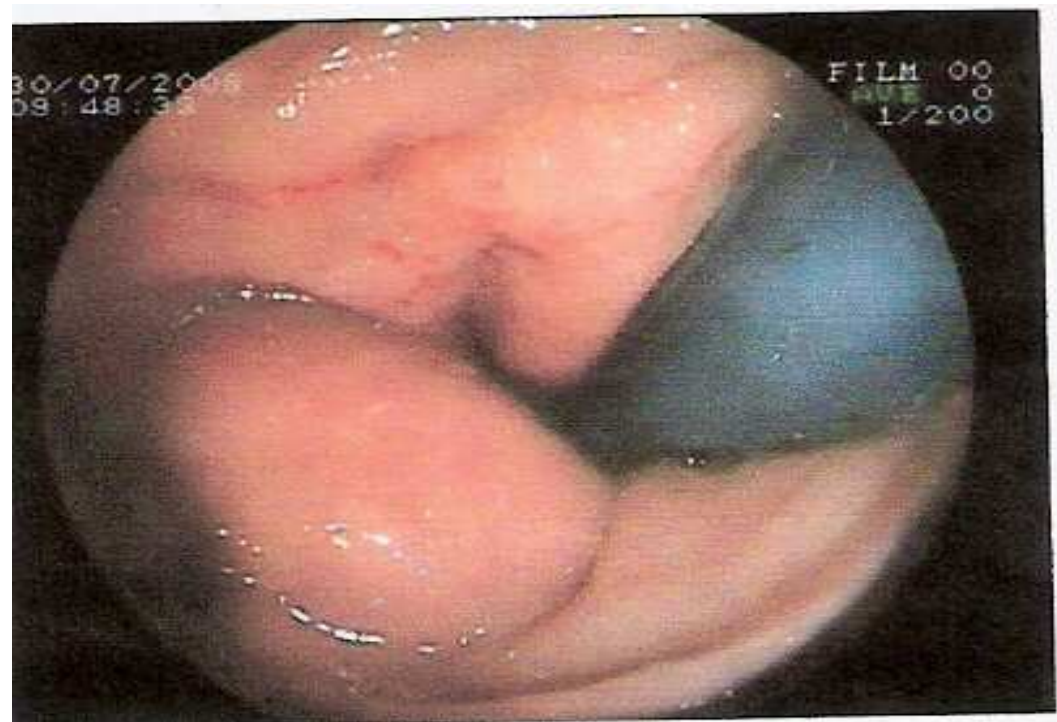

Fig. 1. Colonoscopy: Probably submucosal tumor of $4 \mathrm{~cm}$ in the anterior wall of the lower rectum.

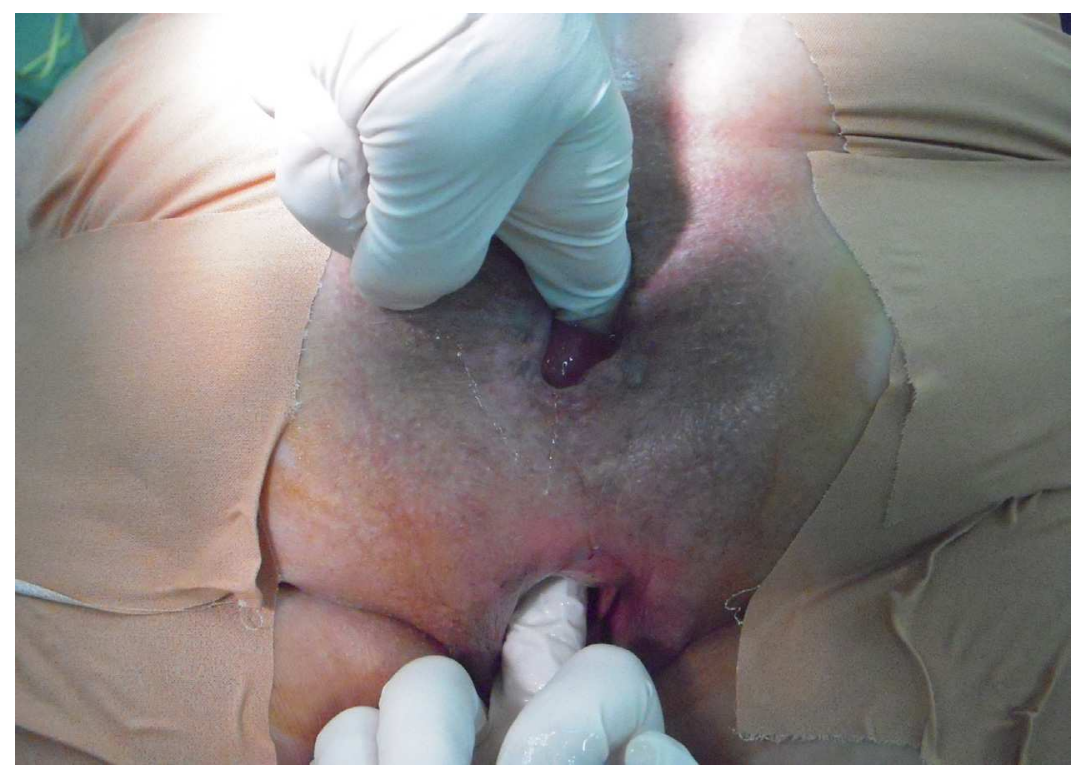

Fig. 2. Pelvic examination revealed a mass between rectum and vagina.

The transvaginal ultrasound showed a normal atrophic internal genitalia; and a tumor welldelimited of about $4-5 \mathrm{~cm}$; the mass appearance was solid with high vascularization. Nuclear magnetic resonance imaging (NMRI) from the abdomen and pelvis was performed, 
and it showed (Fig. 3, 4 and 5.) the origin of the tumor in the anterior wall of the lower rectum. Tumor markers as carcinoembryonic antigen (CEA), alpha-fetoprotein (AFP) and CA 19.9 were negative.

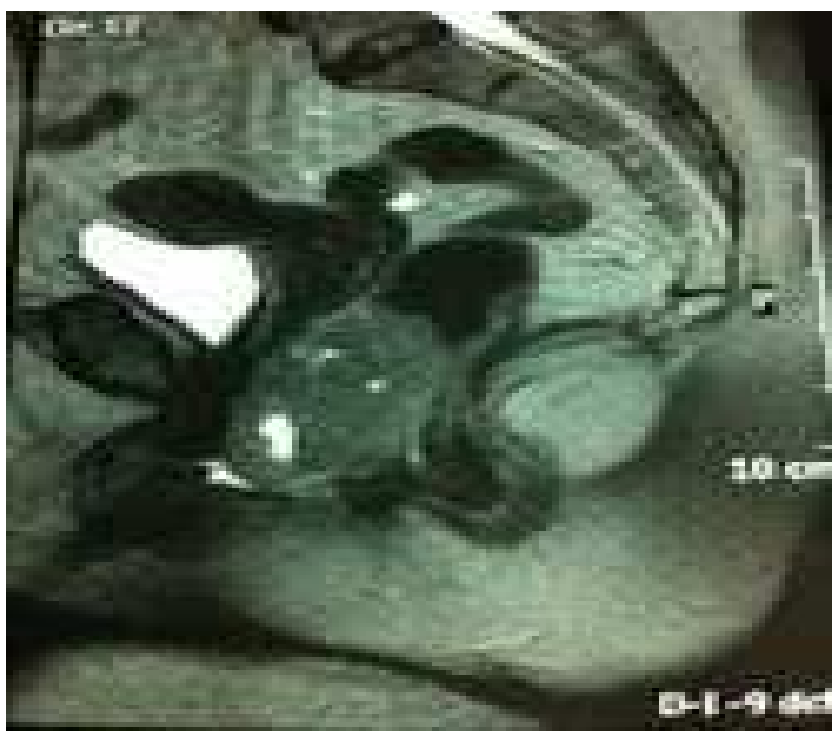

Fig. 3. NMRI that shows the probably origin of the tumor in the anterior wall of the lower rectum.

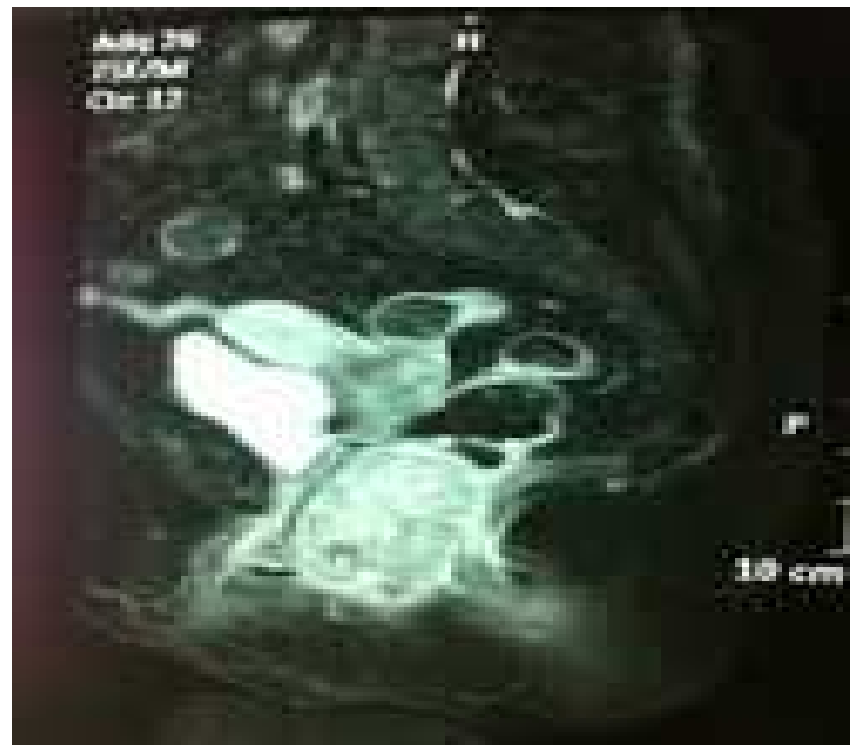

Fig. 4. Another image of NMRI that shows the location of the mass. 


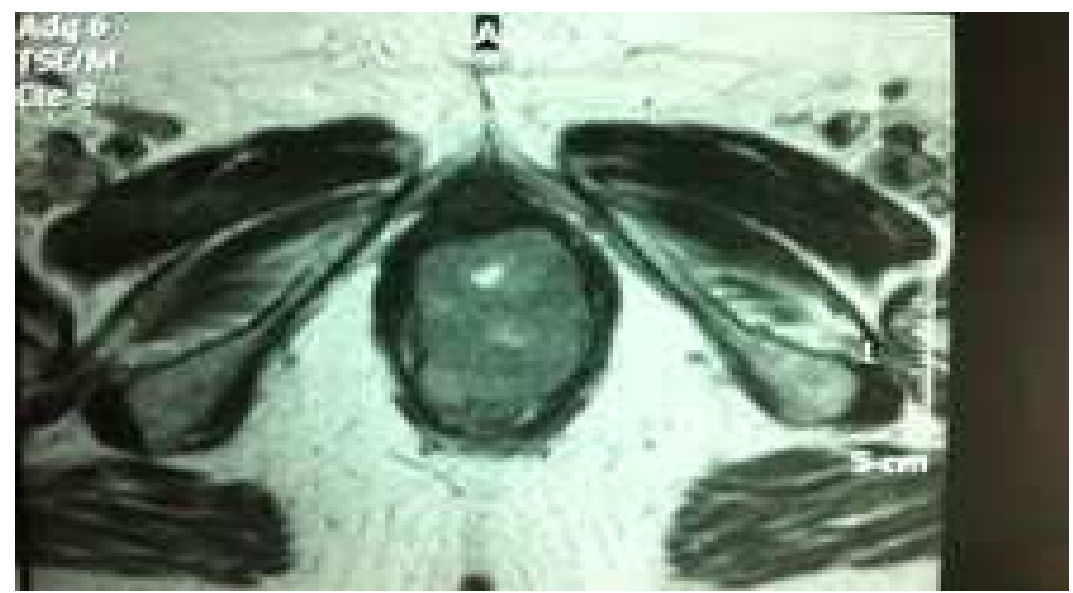

Fig. 5. A transversal section image of NMRI. It shows the mass between vagina and rectum.

Transvaginal biopsy was performed and the specimen was histologically diagnosed as gastrointestinal stromal tumour $(\mathrm{c}-\mathrm{Kit}+)$ of intermediate risk of malignancy.

A transvaginal tumor enucleation was performed with the colaboration of the Department of Surgery, and also perineal reconstruction was done (Fig. 6, 7, 8 and 9).

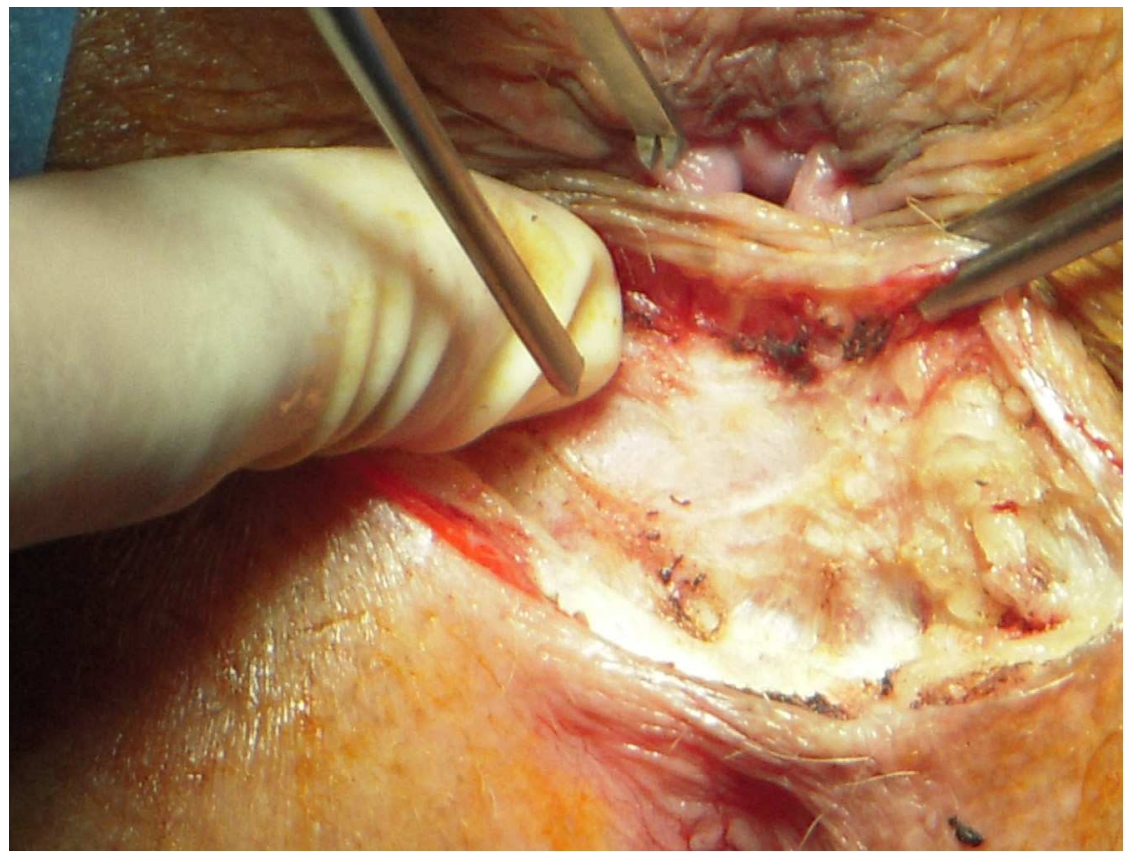

Fig. 6. A transvaginal excision of the tumor was performed. 


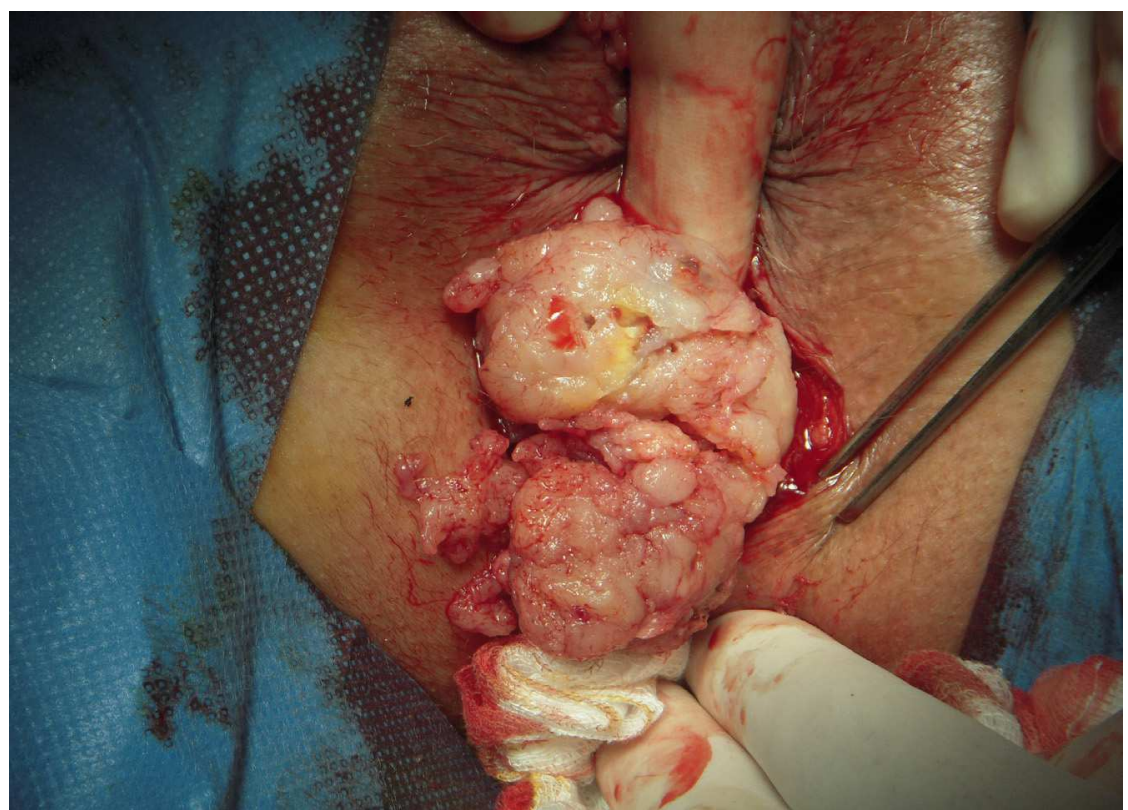

Fig. 7. The tumor was fragile and ruptured during the operation.

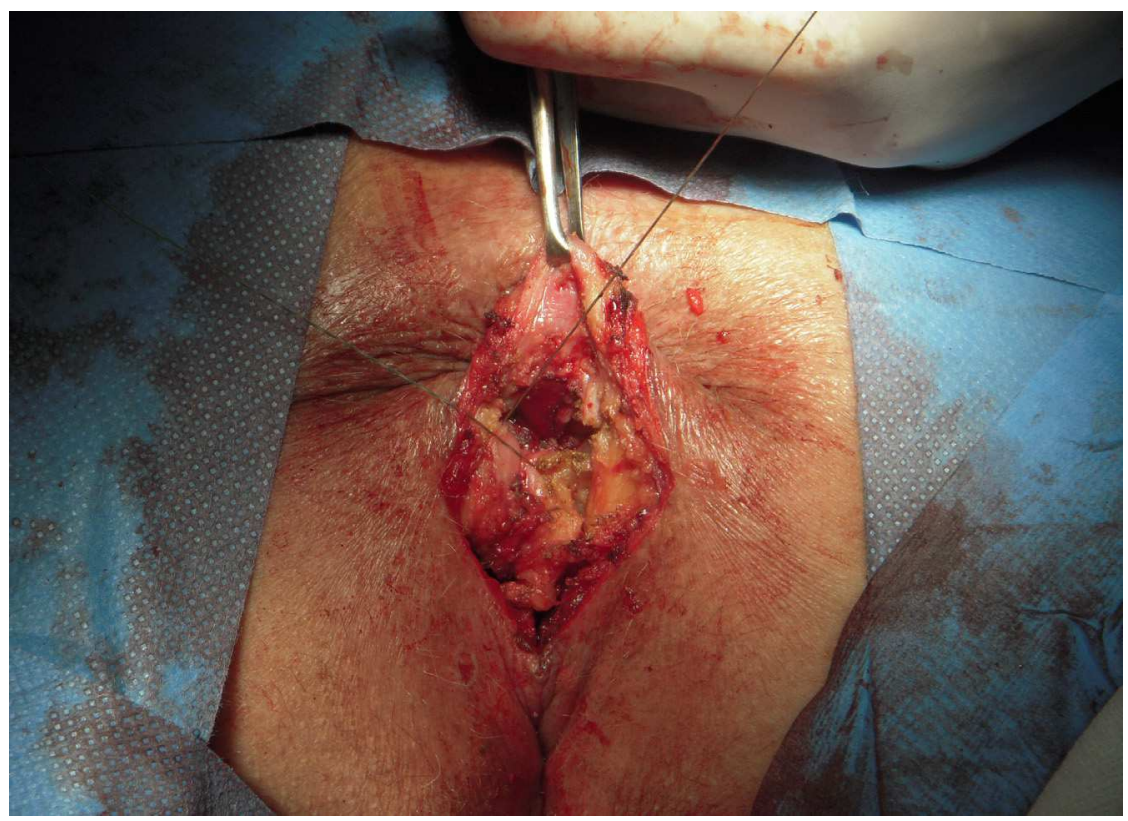

Fig. 8. A perineal reconstruction was also done. 


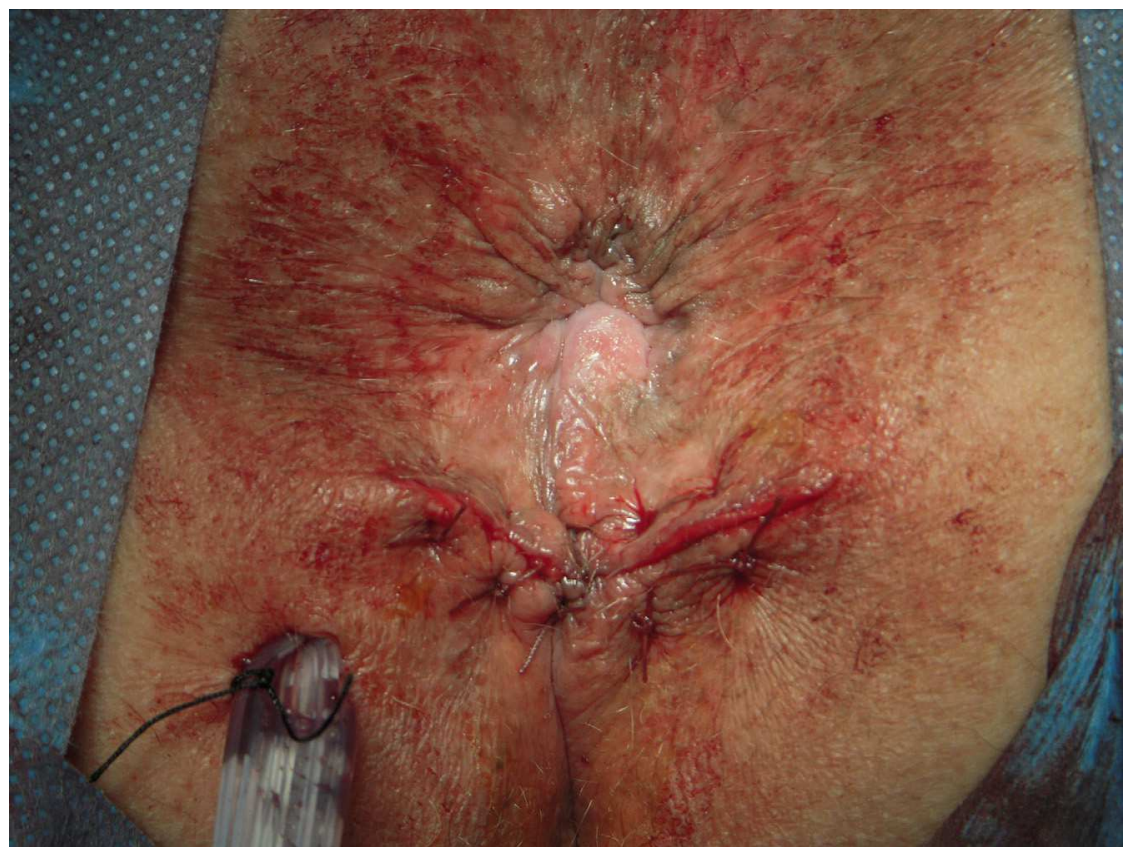

Fig. 9. Final result of the surgery.

The final histological study revealed a gastrointestinal stromal tumour of high risk of malignancy (Fig. 10, 11 and 12) (16 mitotic figures per 50 high power fields, HPF), composed of fascicles of spindle cells with elongated nuclei, fine chromatin, and abundant pale pink, fibrillary cytoplasm. Tumor size and margins could not be evaluated because it had been fragmented during the surgical excision, so because of the high probability of an incomplete

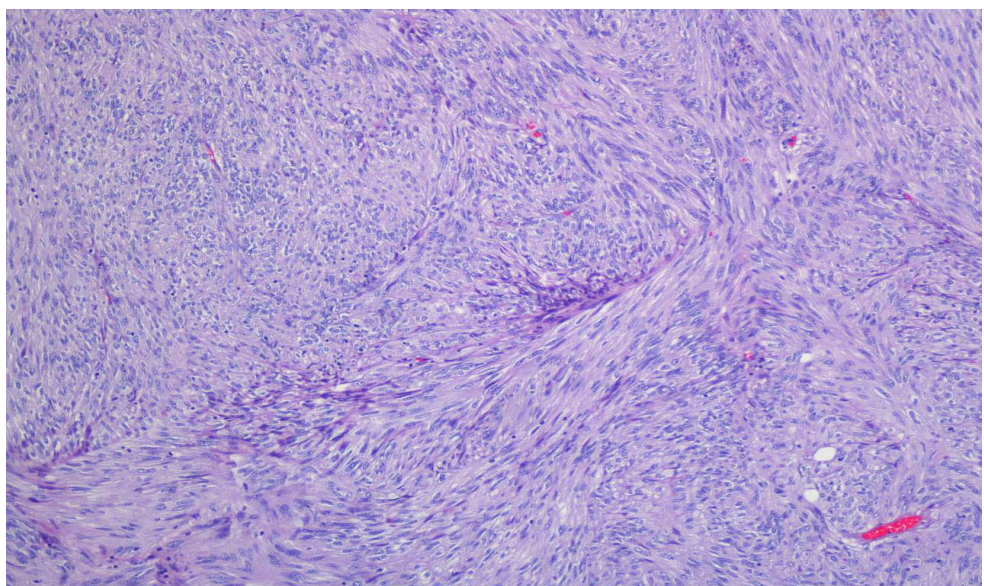

Fig. 10. Fascicles of spindle cells with elongated nuclei, fine chromatin, and abundant pale pink, fibrillary cytoplasm. 
surgey, adyuvant treatment with imatinib mesylate was established without important toxicity (Gleevec ${ }^{\mathrm{TM}}, 400 \mathrm{mg}$ per day in an oral dose). After one year following this treatment, the patient was disease free and now, 3 years later, is following rutinary controls with no evidence of disease.

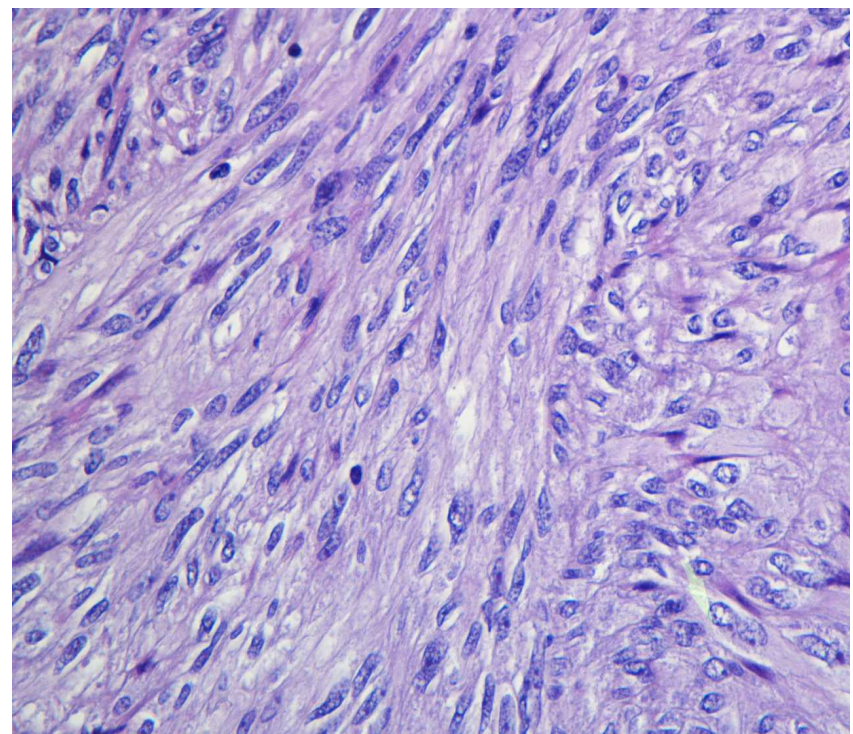

Fig. 11. Original magnification, $x 400$.

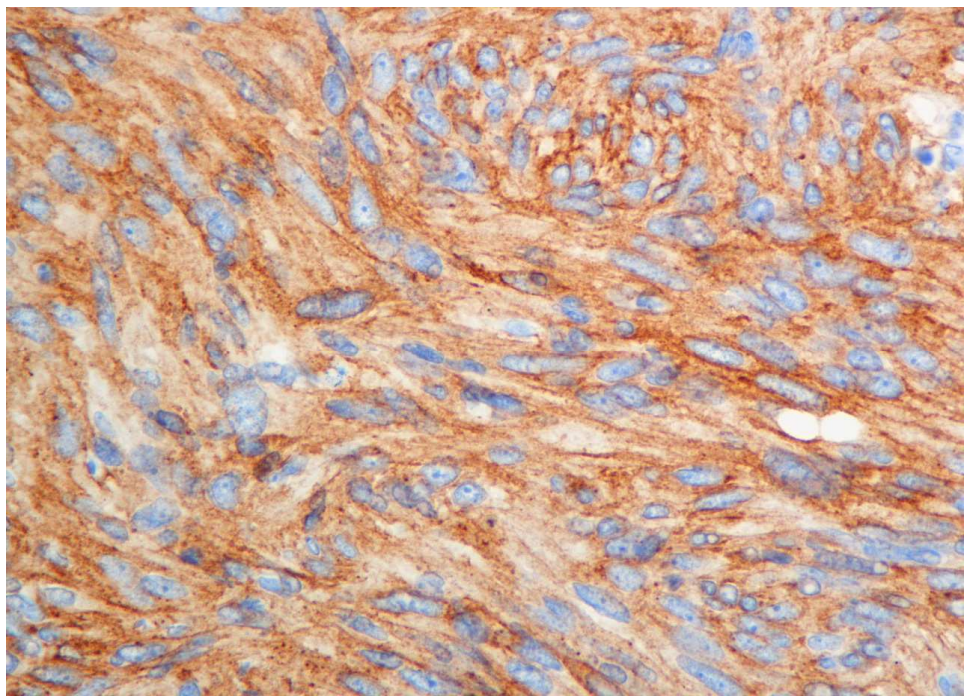

Fig. 12. Inmunohistochemical finding of the tumor cells. Tumor cells show strong and diffuse positivity for immunoreactive $c$-kit (original magnificaction, $x 400$ ) 


\subsection{Discusion}

EGISTs comprises about 5-7\% of all GISTs. The majority of them have involved the mesentery, omentum, and retroperitoneum. Only eleven cases of them presenting as a vaginal mass have been reported previously from 2004 (Table 5). Because EGIST locates in the pelvic cavity, particularly adjacent to the female genital tract, the patient's chief complaints may be compression to local organs leading to symptoms such as urinary frequency and constipation, or a mass with no symptoms. This coincides with the case we presented, in wich the main symptom was a sensation of vaginal mass and constipation. Other alterations that appear with more frequency as a vaginal mass are the cyst (Gartner's duct cysts, Mullerian cysts, bartholin's gland cysts) or recto-vaginal septum endometriosis. The age of diagnosis, 75 years is the elderly of the cases reported. In the eleven cases published the median age was 55 .

The combined vaginal and rectal examination is essential in the diagnosis of recto-vaginal masses to determine the size, mobility and consistency of the tumor. In our case we found a soft, cystic, multi-lobed and not fixed tumor, but in other reported cases, the consistency was hard, that may be related to the size and degree of malignancy.

Transvaginal ultrasound is the most widely used imaging test to complete the diagnosis. A solid mass with low eco levels, similar to the uterine fibroid, is the most characteristic ultrasonographic data. NMRI and CT scans can help to determine the origin, size and relationships of the mass and the overall assessment of the pelvis. In our case, NMRI confirmed the origin of mass in the wall of the rectum.

Histollogically, EGIST often presents as spindle cells and therefore might be excluded from the differential diagnosis of spindle-cell neoplasms and could be confused with the more common leiomyoma or leiomyosarcoma (Lam et al., 2006, Mettinen et al., 2001). Some authors reported that immunohistochemistry with antibodies against c-kit protein (CD 117) and CD 34 is reliable and valuable for diagnosis of EGIST (Connolly et al., 2003; De Matteo et al., 2000; Saund et al., 2004). GIST typically expresses CD117, often CD34 and sometimes SMA and S-100, but its expressions vary depending on different sites.

Since the incidence of rectal-vaginal GIST is much lower than that of GIST in the stomach or small intestine, the clinicopathological profiles have not yet been accurately characterised, and there is therefore the tendency to validate the same prognostic factors for the latter as for such tumors at other sites, particularly gastric GIST. The most important and easily applicable histological criteria for prediction of GIST are its size and mitotic rate. A rate of $\leq$ 5 mitoses per $50 \mathrm{HPF}$ is commonly used as a limit for a tumor with expected benign behaviour, and according to a large study, this can discriminate between benign and malignant tumors, especially gastric GIST.(Miettinen, M. et al, 1999). Tumors of $2 \mathrm{~cm}$ in diameter are generally expected to behave in a benign fashion. Tumors of $5 \mathrm{~cm}-10 \mathrm{~cm}$ in diameter have a better prognosis tan those of $>10 \mathrm{~cm}$ in diameter. Degrees of cellularity and atipia have also been suggested as useful criteria.

It is generally agreed that complete surgical resection with negative tumor margins is the principal curative procedure for primary and non-metastatic tumors, particularly for those at a low risk. Neoadjuvance with imatinib mesilate (Gleevec ${ }^{\mathrm{TM}}$ ) may enhance the resectability of inoperable malignant GIST and may allow for optimal surgical timing. Therapy with imatinib is also used in the adjuvant post-operative treatment of tumors at a high risk or in cases of incomplete surgical resection. In five of the eleven cases surgery was the treatment done as first option, in two more cases (like the one we report) tumor escision and treatment 
with imatinib mesylate was established. Only in one case, there was evidence of metastatic disease, and treatment with imatinib mesylate was the therapeutic choice. In ten of the eleven cases reported, the diagnosis of the tumor was before evidence of metastatic disease, probably because the location in the rectovaginal septum affords an early detection.

\begin{tabular}{|c|c|c|c|c|c|c|c|}
\hline $\begin{array}{l}\text { Author } \\
\text { (publication } \\
\text { year) }\end{array}$ & \begin{tabular}{|l} 
Age \\
(years)
\end{tabular} & $\begin{array}{l}\text { Tumor } \\
\text { size } \\
(\mathrm{cm})\end{array}$ & Treatment & $\begin{array}{l}\text { Mitosis } \\
(\sqrt{50} \\
\text { HPF })\end{array}$ & $\begin{array}{l}\text { Kit } \\
\text { (CD117) }\end{array}$ & CD34 & Outcome \\
\hline Nasu (2004) & 54 & 8.5 & Surgery & $5-10$ & + & + & $\begin{array}{l}\text { Alive and } \\
\text { well } 13 \\
\text { months }\end{array}$ \\
\hline \begin{tabular}{|l|} 
Ceballos \\
$(2004)$
\end{tabular} & 75 & 4.5 & Surgery & $12-15$ & + & + & \begin{tabular}{|l|} 
Recurrence \\
7.5 years
\end{tabular} \\
\hline $\begin{array}{l}\text { Weppler } \\
(2005)\end{array}$ & 66 & 8 & Imatinib & $>5$ & + & + & $\begin{array}{l}\text { Not } \\
\text { described }\end{array}$ \\
\hline $\begin{array}{l}\text { Takano } \\
(2006)\end{array}$ & 38 & 7 & Surgery & $1-2$ & + & + & $\begin{array}{l}\text { Alive and } \\
\text { well } 12 \\
\text { months }\end{array}$ \\
\hline Lam (2006) & 36 & 4 & Not described & 15 & + & + & $\begin{array}{l}\text { Recurrence } \\
2 \text { years }\end{array}$ \\
\hline Lam (2006) & 48 & 6 & Not described & 12 & + & + & \begin{tabular}{|l|} 
Recurrence \\
10 years
\end{tabular} \\
\hline Lam (2006) & 61 & 8 & Not described & 16 & + & + & $\begin{array}{l}\text { Not } \\
\text { described }\end{array}$ \\
\hline $\begin{array}{l}\text { Nagase } \\
(2007)\end{array}$ & 42 & 3.5 & Surgery & $<1$ & + & + & $\begin{array}{l}\text { Alive and } \\
\text { well } 4 \text { years }\end{array}$ \\
\hline $\begin{array}{l}\text { Nagase } \\
(2007)\end{array}$ & 66 & 5 & Surgery+Imatinib & $2-3$ & + & + & $\begin{array}{l}\text { Alive and } \\
\text { well } 6 \\
\text { months } \\
\end{array}$ \\
\hline Zang (2009) & 42 & 8 & Surgery & 10 & + & + & $\begin{array}{l}\text { Alive and } \\
\text { well } 6 \\
\text { months } \\
\end{array}$ \\
\hline $\begin{array}{l}\text { Marcos } \\
(2010), \text { the } \\
\text { current case }\end{array}$ & 75 & 5 & Surgery+Imatinib & 16 & + & + & $\begin{array}{l}\text { Alive and } \\
\text { well till } \\
\text { now }\end{array}$ \\
\hline
\end{tabular}

Table 5. Clinicopathologic features of eleven reported cases of EGISTs presenting as a vaginal mass (Zang, 2009).

As lymph nodes metastasis occurs infrequently $(<10 \%)$, extensive lymphadenectomy need not to be done (Miettinen, M. et al, 1999). But despite complete resection with pathologically confirmed negative margins, the majority of tumors recur. In the eleven published cases, five recurred from several months to ten years after primitive treatment. While the majority of patients initially benefit from tyrosine kinase inhibitors, it is now clear that resistance commonly develops. Indeed, the median time to progression on imatinib mesylate is 2 years (De Matteo et al., 2007). 
In our case, the final histological study revealed a gastrointestinal stromal tumor of high risk of malignancy (16 mitotic figures per 50 high power fields). We used Gleevec ${ }^{\mathrm{TM}}$ as neoadjuvant therapy. The patient showed good tolerance to the drug. Evolution has been very favorable, almost three years have passed and our patient is alive and free of disease.

The lack of a large series of patients under long-term follow-up observations makes it difficult to assess the necessary extent of surgical resection and the indication for treatment with imatinib.

\section{Conclusion}

In the past years there have been significant developments in the understanding of GISTs and their response to therapy. Many questions remain unanswered and new issues have arisen as the benefits of imatinib mesylate therapy are revealed.

EGISTs that present as gynecologic masses are rare but may be more common than is currently recognized. Misdiagnosis may lead to an inappropriate therapy because conventional radiotherapy and chemotherapy are not effective in the treatment of GISTs, whereas imatinib mesylate (Gleevec ${ }^{\mathrm{TM}}$ ) has a proven role in managing these tumors. Thus, it is important and necessary to consider EGISTs in the differential diagnosis of mesenchymal neoplasms in the vulvovaginal-rectovaginal septum. The most common symptom is due to compression of adjacent organs, discomfort, feeling of lump, dyspareunia or constipation The differential diagnosis is done with leiomyomas and vaginal cysts (Gartner's duct cysts, Mullerian cysts, bartholin's gland cysts). GIST typically expresses CD117, often CD34 and sometimes SMA and S-100, leading to the definitive diagnosis in the biopsy samples. The prognosis is determined by the size and mitotic count. Treatment relies on surgical excision of the tumor, and imatinib mesylate has shown efficacy as neoadjuvant and adjuvant monotherapy.

\section{Acknowledgment}

We want to thank the Surgery and Pathology Department of our hospital for their help in the management of this case.

\section{References}

Ceballos, K.M.; Francis, J.A. \& Mazurka, J.L. (2004). Gastrointestinal stromal tumor presenting as a recurrent vaginal mass. Archives of Patholgy and Laboratory Medicine, Vol.128, No.12 (December 2004), pp.1442-1444, ISSN 0003-9985.

Connolly, E. M. ; Gaffney, E. \& Reynolds, J. V. (2003). Gastrointestinal stromal tumors. British Journal of Surgery, Vol.90, No.10, (October 2003), pp.1178-1186, ISSN 13652168.

De Matteo, R. ; Lewis, J. ; Leung, D. ; Mudan, S. ; Woodruff, \& J. Brennan, M. (2000). Two hundred gastrointestinal stroma tumours. Recurrence patterns and prognostic factors of survival. Annals of Surgery, Vol.231, No.1, (January 2000), pp. 51-58, ISSN 0003-4932.

De Matteo, R.; Marki, R.; Singer, S.; Gonen, M. ; Brennan, M. \& Antonescu, C. (2007). Results of tyrosine kinase inhibitor therapy followed by surgical resection 
for metastatic gastrointestinal stromal tumour. Annals of Surgery, Vol.245, No.3, (March 2007), pp. 347-352, ISSN 0003-4932.

Fletcher, C.D. ; Berman, J.J. ; Corless, C. ; Gorstein, F. ; Lasota, J. ; Longley, B.J. et al. (2002). Diagnosis of gastrointestinal stromal tumors: a consensus approach. Human Pathology, Vol.33, No.5, (May 2002), pp. 459-465, ISSN 0046-8177.

Hellan, M. \& Maker, V. (2006). Transvaginal excision of a large rectal stromal tumour: an alternative. Americal Journal of Surgery, Vol.191, No.1, (January 2006), pp.121-123, ISSN 0002-9610.

Lam, M.; Corless, C.; Goldblum, J.; Heinrich, M.; Downs-Kelly, E. \& Rubin, B. (2006) Extragastrointestinal stromal tumours presenting as vulvovaginal/rectovaginal septal masses: A diagnostic pitfall. International Journal of Gynecological Pathology, Vol.25, No.3, (July 2006), pp. 288-292, ISSN 0277-1691.

Marcos, J.; Román, M.J.; Esteve, N.; Saco, A.; Piñero, O.; Candela, A.; López, J.A.; Muci, T. \& Martínez, J.C. (2010). Gastrointestinal stromal tumor of the rectovaginal septum: a diagnostic challenge. Progresos de Obstetricia y Ginecología, Vol.53, No.7, (July 2010), pp. 288-291, ISSN 0304-5013.

Miettinen, M.; Monihan, J.M.; Sarlomo-Rikala, M.; Kovatich, A.J.; Carr, N.J.; Emory, T.S.; et al. (1999). Gastrointestinal stromal tumors/smooth muscle tumors (GISTs) primary in the omentum and mesentery: clinicopathologic and immunohistochemical study of 26 cases. The American Journal of Surgical Pathology, Vol.9, No.23, (September 1999), pp.1109-1118, ISSN 0147-5185.

Miettinen, M:, Furlong, M.; Sarlomo-Rikala, M.; Burke, A.; Sobin, L.H. \& Lasota, J.(2001). Gastrointestinal stromal tumors, intramural leiomyomas, and leiomyosarcomas in the rectum and anus: a clinicopathologic, immunohistochemical, and molecular genetic study of 144 cases. The American Journal of Surgical Pathology, Vol.25, No.9, (September, 2001), pp. 1121-1133, ISSN 0147-5185.

Mussi, C.; Jakob, J.; Wardelmann, E.; Reichardt, P.; Casali P.G. \& Fiore, M. (2008). Gastrointestinal stromal tumor of the rectum and rectovaginal space: A retrospective review [abstract 10560]. Journal of Clinical Oncology, Vol.26, No.2, (May 2008), pp. 347-352, ISSN 1527-7755.

Nagase, S.; Mikami, Y.; Moriya, T.; Niikura, H.; Yoshinaga, K.; Takano, T. et al. (2007). Vaginal stromal tumors with histologic and immunohistochemical feature of gastrointestinal stromal tumor: two cases and review of the literature. International Journal of Gynecological Cancer. Vol.17, No.4, (July-August 2007),pp.928-933, ISSN 1048-891X.

Nickl, N. (2004). Gastrointestinal stromal tumors: new progress, new questions. Current Opinion in Gastroenterology, Vol.20, No.5, (September 2004), pp. 482-487, ISSN 02671379.

Nasu, K.; Ueda, T.; Kai, S.; Anai, H.; Kimura, Y.; Yokoyama, S. et al. (2004). Gastrointstinal stromal tumor arising in the rectovaginal septum. International Journal of Gynecological Cancer, Vol.14, No.3, (March 2004), pp.373-377, ISSN 1048-891X.

Parck, C.K.; Lee, E.J.; Kim, M.; Lim, H.; Choi, D.; Noh, J.H. et al. (2008). Prognostic stratification og high-risk gasrrointestinal stromal tumours in the era of targeted therapy. Annals of Surgery, Vol.247, No.6, (June 2008), pp.1011-1018, ISSN 00034932. 
Pasku, D. ; Karantanas, A. ; Giannikaki, E. ; Tzardi, M. ; Velivassakis, E. \& Katonis, P. (2008). Bilateral gluteal metastatses from a misdiagnosed intrapelvic gastroinestinal stromal tumor. World Journal of Surgical Oncology. Vol.139, No.6, (December 2008), ISSN 14777819.

Pidhorecky, I. ; Cheneky, R.T. ; Kraybill, W.G. \& Gibbs, J.F. (2000). Gastrointestinal stromal tumors : current diagnosis, biologic behaviour, and management. Annals of Surgical Oncology, Vol.7, No.9, (September 2000), pp.705-712. ISSN 1068-9265.

Raut, C. ; Morgan, J. ; Ashley, S. (2007). Current issues in gastrointestinal stromal tumors: incidence, molecular biology, and contemporary treatment of localized and advanced disease. Current opinion in Gastroenterology, Vol.2, No.23, (March 2007), pp.149-158, ISSN 0267-1379.

Reid, R.; Bulusu, R.; Buckels, J.; Carroll, N.; Eatock, M.; Geh, I. et al. (2005). Guidelines for the management of gastrointestinal stromal tumours (GISTs). Available from: http:/ / www.augis.org/news/articles/gist mngmnt gdlns 071205 final.pdf.

Ronellenfitsch, U.; Mussi, C.; Wardelmann, E.; Jakob, J.; Fumagalli, E.; Tamborini, E. et al. (2008). Surgery in patients with metastatic or recurrent gastrointestinal stromal tumours (GIST) upon best response o limited progression following imatinib therapy [abstract 10555]. Journal of Clinical Oncology, Vol.26, Supplement, (May 2008), ISSN 1527-7755.

Saund, M.; Demetri, G. \& Ashley, S. (2004). Gastrointestinal stromal tumours. Small intestine. Current Opinion in Gastroenterology, Vol.20, No.2, (March 2004), pp.89-94, ISSN 0267-1379.

Taniguchi, M.; Nishida, T.; Hirota, S.; Isozaki, K.; Ito, T.; Nomur, T. et al. (1999). Effect of ckit mutation on prognosis of gastrintestinal stromal tumors. Cancer Research, Vol.59, No.9, (September 1999), pp.4297-4300, ISSN 0008-5472.

Takano, M.; Saito, K.; Kita, T.; Furuya, K.; Aida, S. \& Kikuchi, Y. (2006). Preoperative needle biopsy and immunohistochemical analysis for gastrointestinal stromal tumor of the rectum mimicking vaginal leiomyoma. International Journal of Gynecological Cancer, Vol.16, No.2, (March-April 2006), pp.927-930, ISSN 1048-891X.

Tooru, O.; Jum, K.; Takahiro, S.; Mikio, F.; Shiro, N.; Tetsuhiko, M. et al. (2001). A case of gastrointestinal stromal tumour of the rectovaginal septum. Journal of Japan Surgical Association, Vol.62, No.4, (April 2001), pp.988-991, ISSN1345-2843.

Valera, Z.; Sánchez, M.; Díaz, C.; Blanco, M.A.; Socas, M. \& Serrano, I. (2008). GIST rectal. Revista Española de Enfermedades Digestivas, Vol.100, No.6, (June 2008), pp.374-375, ISSN 1130-0108.

Verma, J.; Younus, D.; Styr-Norman, A.E.; Haynes, M.; Blackstein, D. \& the Sarcoma Disease Site Group. (2006). Imatinib Mesylate (Gleevec ${ }^{\mathrm{TM}}$ ) for the treatment of adult patients with unresecable or metastatic gastrointestinal stromal tumours: A clinical practice guideline. Evidence-based series. A Quality initiative of the Program in Evidence-Based Care, Cancer Care Ontario (April 2006). Section 1:1-3.

Verweij, J.; Casali, P.G.; Zalcberg, J.; LeCesbe, A.; Reichardt, P.; Blay, J.Y., et al. (2004). Progression-free survival in gastrointestinal stromal tumours with high dose imatinib: randomised trial. The Lancet, Vol.364, No.9440, (september 2004), pp. 11271134, ISSN 0140-6736.

Weppler, E.H. \& Gaertner, E.M.(2005). Malignant extragastrointestinal stromal tumor presenting as a vaginal mass: report of an unusual case with a literature review. 
International Journal of Gynecological Cancer. Vol.15, No.6, (November 2005), pp.11691172, ISSN 1048-891X.

Yamamoto, H.; Oda, Y.; Kawaguchi, K.; Nakamura, N.; Takahira, T.; Tamiya, S. et al. (2004). C-kit and PDGFRA mutations in extragastrointestinal stromal tumor (gastrointestinal stromal tumor of the soft tissue). The American Journal of Surgical Pathology, Vol.28, No.4, (April, 2004), pp. 479-488, ISSN 0147-5185.

Zalupski, M.; Metch, B.; Balcerzak, S.; Fletcher, W.S.; Chapman, R.; Bonnet, J.D. et al. (1991). Phase III comparison of doxorubicin and dacarbazine given by bolus versus infusion in patients with soft-tissue sarcomas: a Southwest Oncology Group study. Journal of the National Cancer Institute, Vol.83, No.13, (July 1991), pp. 926-932, ISSN 0027-8874.

Zang, W.; Peng, Z. \& Xu, L. (2009). Extragastrointestinal stromal tumor arising in the rectovaginal septum: Report og an unusual case with literature review. Gynecologic Oncology, Vol.113, No.3, (June 2009), pp.399-401, ISSN 0090-8258. 


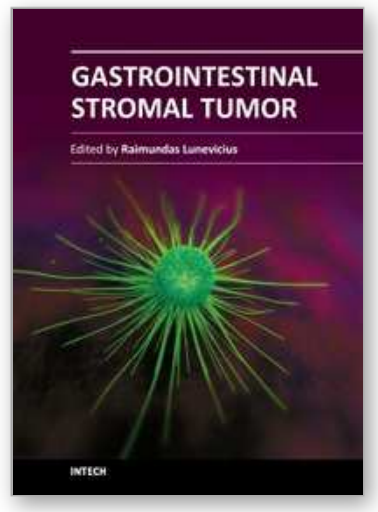

\author{
Gastrointestinal Stromal Tumor \\ Edited by Prof. Raimundas Lunevicius
}

ISBN 978-953-51-0580-0

Hard cover, 120 pages

Publisher InTech

Published online 27, April, 2012

Published in print edition April, 2012

Almost 30 years have gone by since the postulation that GISTs derive from mesenchymal stem elements, and only 15 years have gone by since the definitive detection of origin of GISTs. Research in the last decade was more focused upon the justification of imatinib mezylate therapy in GISTs and clarification why a secondary resistance that occurred during the kinase inhibitors therapy. The era of therapy for GISTs, targeting the primary activating mutations in the KIT proto-oncogene; is being proclaimed as bringing the message of special importance to the pathologist role in multidisciplinary team that are responsible for treating patients with locally advanced or metastatic GIST. This is the first conclusive message forthcoming from this book. On the other hand, the book provides summarised and case-based knowledge on current management of gastrointestinal and extragastrointestinal stromal tumours. We hope that this book may be considered as a worthwhile timely addition to clinical science dissemination, medical education, further basic and clinical research.

\title{
How to reference
}

In order to correctly reference this scholarly work, feel free to copy and paste the following:

Josefa Marcos Sanmartin, Maria Jose Roman Sanchez, Jose Antonio Lopez Fernandez, Óscar Pinero Sanchez, Amparo Candela Hidalgo, Hortensia Ballester Galiana, Natalia Esteve Fuster, Aranzazu Saco Lopez and Juan Carlos Martínez Escoriza (2012). Gastrointestinal Stromal Tumor of the Rectovaginal Septum, a Diagnosis Challenge, Gastrointestinal Stromal Tumor, Prof. Raimundas Lunevicius (Ed.), ISBN: 978-953-510580-0, InTech, Available from: http://www.intechopen.com/books/gastrointestinal-stromaltumor/gastrointestinal-stromal-tumor-of-the-rectovaginal-septum-a-diagnosis-challenge

\section{INTECH}

open science / open minds

\section{InTech Europe}

University Campus STeP Ri

Slavka Krautzeka 83/A

51000 Rijeka, Croatia

Phone: +385 (51) 770447

Fax: +385 (51) 686166

www.intechopen.com

\section{InTech China}

Unit 405, Office Block, Hotel Equatorial Shanghai

No.65, Yan An Road (West), Shanghai, 200040, China

中国上海市延安西路65号上海国际贵都大饭店办公楼405单元

Phone: +86-21-62489820

Fax: +86-21-62489821 
(C) 2012 The Author(s). Licensee IntechOpen. This is an open access article distributed under the terms of the Creative Commons Attribution 3.0 License, which permits unrestricted use, distribution, and reproduction in any medium, provided the original work is properly cited. 